\title{
Innovation, SMEs, and the Entrepreneurship Education Related to Them
}

\section{Ermira Qosja}

\author{
Associated Professor PhD - European University of Tirana \\ ermira.qosja@uet.edu.al
}

\section{Doi:10.5901/jesr.2014.v4n6p69}

\begin{abstract}
The massification of the higher education; the form of organization of Albanian companies, where most of them are micro and small enterprises; as well as the necessity to compete in a market which is everyday becoming more globalized and where the new technologies everyday innovate products and services raise the requirement to also include in the university curricula, beyond the economic and engineering sciences, subjects closely associated with entrepreneurship, business start-up, managing a business during the first years and drafting of a simple growth and marketing plan (Drucker, 1985). The European Commission programs and directives, as well as the European experience about entrepreneurship education, will be elaborated in this study, aiming to confront them with the present situation of our universities and to represent the need to set up entrepreneurship chairs and business incubators in them. The entrepreneurship education requires the identifying of an instrument that would commit together universities, businesses and public institutions, so that the resulting output of the collaboration would be the innovation and the success of business enterprises in market, as well as diminishing unemployment rates and achieving economic growth for the country.
\end{abstract}

Keywords: entrepreneurship education, innovation, start-up, entrepreneurship mentality, self-confidence

\section{Introduction}

Albania signed in Berlin, in 2003, the Bologna Charter, which brought about a series of reforms in the higher education. In the framework of the Charter, the higher education was reorganized in three levels: BA, MA (professional and scientific) and doctorate studies; the credit system of evaluating the duration of study was recognized; a quality system process was put in place. All these were done to assist the higher education market liberalization and to support the mobility of students and lecturers, within and outside the country.

Liberalization of the tertiary education market, as well as the growing competition in the labor market, brought about the massification of the higher education, which is reflected in the growing number of students by $56 \%$ from 2006 to 2011 (Ministry of Education and Science [Ministria e Arsimit dhe Shkencës], 2012), for all the three levels: BA, MA, and $\mathrm{PhD}$.

The 2009 Work Force Survey, conducted by INSTAT, in relation to the education level of those employed, indicates that only $12.8 \%$ of them have a university degree, or about 119457 persons (INSTAT, 2009). Meanwhile, the number of students registered in the three levels of higher studies during 2011 alone is 134877 (MES, 2012).

The official data on unemployment (INSTAT, 2009) shows that the unemployment rate in 2009 was $13.8 \%$, meanwhile the rapport level between the youth of $15-24$ years of age unemployment rate against the adults of $25-64$ years of age unemployment rate is 2.4 , which means that the chances of youngsters to find a job are 2.4 times smaller than those of an adult. It is important to note that the unemployment rate during the second trimester of 2012 was almost at the same level, at 13.3\% (INSTAT, 2012), yet the data on unemployment rate for the age groups could not be found, since the last Work Force Survey dates back to 2009.

In relation the structure of those employed, public administration represents $16.7 \%$. Meanwhile, in inland migration has brought about a shift of the population from rural areas towards the urban and suburban areas. As of today, $53.7 \%$ of the population lives in cities and $46.3 \%$ in villages (INSTAT, 2011). As a result, employment in the private sector (nonagricultural) is a priority, and this is also shown by the 2009 Work Force Survey, where $40 \%$ of those employed are engaged in the private non-agricultural sector. It should also be noted that the structure of business in Albania is such that $99.8 \%$ of the businesses are SMEs and $96 \%$ of all businesses are micro businesses (INSTAT, 2010. In other words, they are enterprises with $1-4$ employees.

This data goes to show a few phenomena: first of all, the growth of urban population; secondly, the growth of those 
university educated; thirdly, the growth of those employed in the non-agricultural private sector; fourthly, the high rate of unemployment among the youth of $15-24$ years of age; and, lastly, the personal enterprises are the main source of employment in the country.

The above shown data clearly indicate that the education reforms and the economic and social development of the country emphasize the new challenges to the higher education. Studying in a university is now a right for everybody in Albania, yet earning a diploma is no longer a privilege that is converted into a job.

To this end, universities face the need to gradually transform into entrepreneurship universities, because the entrepreneurship mentality of the youth must be stimulated, innovative business start-ups must be encouraged, an amiable culture towards entrepreneurship must be groomed (Smith \& Petersen, 2006).

\section{Objectives and Limitations of the Research}

The objective of this study is to show the necessity of entrepreneurship education in the higher education in Albania as a very important way to promote creativity, innovation dh self-employment, in the social and economic context where we live. At the same time, this study aims to identify how our higher education forms the entrepreneurship mentality, how much self-confidence instills our higher education in the students, and whether they see entrepreneurship as a career possibility or a way to enter into the job market. Furthermore, we will try to identify new ways to be followed in order to create an entrepreneurship environment within universities.

A full research would require information on university curricula, because entrepreneurship education is beyond business and economic studies, meanwhile the curricula is part of the intellectual property of universities and, as such, it is not so simple to have them at our disposition, and this represents a limitation.

Another limitation is related to the fact that measuring entrepreneurship education requires data about the employment of students, but universities have not yet implemented systems of tracing the students' career after they graduate.

\section{Hypothesis and Research Questions}

This research will try to analyze the role of universities in creating the entrepreneurship mentality and self-confidence in the students to undertake business initiatives. The research will also try to furnish way and modes to transform universities into entrepreneurship universities.

The research questions raised in this study are: Does our higher education assure the development of entrepreneurship capabilities and mentality? Are students convinced that self-employment is one of the ways to enter the job market? Is entrepreneurship studied in other faculties, apart from those of business, economics and engineering? Is the law on academic titles and degrees an obstacle for including entrepreneurs and business executives in universities?

Hypothesis of the research: the BA - MA study cycle does not create premises for the development of entrepreneurship mentality and self-confidence in students, so that self-employment can be a way to enter the job market.

\section{The Methodology Employed}

The research is built upon a series of reports and studies on entrepreneurship education, which treat widely on European experiences, as well as on some very important data from Ministry of Education and Science, INSTAT. We have also employed a primary research involving BA and MA students of the European University of Tirana.

\section{What Entrepreneurship Education Aims in the Higher Education?}

European Council, in its 2000 summit in Lisbon, decided on a new strategic objective for the EU, which is "the economy to become more competitive and dynamic in the world, based on knowledge, able to grow and assure more quantitative and qualitative work, as well as a greater social cohesion." A work-group, set up by the European Commission, comprised of experts from different EU countries, identified eight primary competences for an individual in a society based on knowledge, which, in a nutshell, represent a transferable multifunctional package of know-how and behavior needed for their personal development, for the inclusion in the labor market (European Commission, 2004). Such base competences are divisible in eight fields: (i) communication in the native language; (ii) communication in foreign 
languages; (iii) knowledge of mathematics, sciences and technology; (iv) digital competence; (v) learning to learn; (vi) social and civic competences; (vii) entrepreneurship; (viii) cultural expression.

The definition of "entrepreneurship" competence is made of an active and a passive component, which together help bring in the innovative tendencies and the possibilities to welcome the innovation from outer factors. This is what supports everyone in their daily life at home and in society, making workers more responsible for the wider context of the work they do and more efficient in calculating opportunities, and furnishing a foundation for the entrepreneurs to stabilize their trade and social activities (Commission Communication, 2006).

Entrepreneurship education should not be mistaken or confused with the general studies on business and economics. Its main objective is to promote creativity, innovation and self-employment, and could also include the mentioned elements (European Commission, 2008): (i) development of personal attributes and manners which form the foundation of an entrepreneurship mentality and positioning (creativity, sense of initiative, risk undertaking, autonomy, self-evaluation, leadership, group spirit, etc.); (ii) awareness of students about self-employment and entrepreneurship as a career; (iii) work on real enterprise projects and activities; (iv) offering specific business knowledge and manners on how to set up a company, how to drive it forward successfully.

The main objective of entrepreneurship education in the higher education is the development entrepreneurship abilities and mentality. The entrepreneurship study programs could have different objectives, such as: creating awareness among students and helping them towards the long road during an enterprise; treating students as to what is needed in setting up a business and managing its growth, exploring business opportunities (European Commission, 2012). On the other hand, the business schools are not the only place to learn entrepreneurship, because business ideas and innovation could come, in greater part, from technical, scientific and creative studies (European Commission, 2008).

The teaching content should differ for those studying business and for those taking non-business studies, or the content could be similar, however, the teaching method should be different (Ruskovaara, Pihkalam Rytkola \& Leino, 2010). There is a general perception that engineering and science students value more the practical methods, but, as it is also generally accepted, these students need to have more elements of economics, marketing and management techniques. So, the best way to motivate students of other areas of study is through practical examples from their field of study.

Non-business students often are better technically and have stronger ideas about products, yet they are weak in commercialization and marketing areas. Such students need to be lectured on the intellectual property rights, commercialization process, marketing and capital risk. The objective should be, independent of the technical faculties they are working on, that they should take into consideration the entrepreneurship aspects, as well. In fact, many of the non-business student aim to product-oriented in their business attitude, and they do not understand that there is not so important how much innovative is the product, if the market has no need for such a business. This would avoid the great mistake that new entrepreneurs make, in developing a product before probing if the market is favorable and considers it as a potential business.

On the other hand, teaching entrepreneurship to economics and business students is narrow in scope, just like in the selective manner other competences of economics studies are offered (marketing, management, etc.). In this context, the entrepreneurship education should emphasize more the start-up and growth phase of the SMEs. The teaching process, in this case, requires experience and opportunities in business and enterprises. In order to teach the entrepreneurship attitudes and behavior, and to have an impact on the young students, it is not enough to simply know about enterprises. It is not only about teaching methods and contents, but about the whole learning environment.

Many experts agree that the objectives, content and teaching methods could be differentiated according to the level of education (European Commission, 2008). For the BA students, the most important thing is to mainly work on the mentality and to stimulate the interest in self-employment and business creating (elements of awareness and motivation). For the graduating students, there is a need for more technical and practical instruments (such as business plan competitions), and genuine support for business ideas. However, the Bologna process aims to make the BA appropriate to enter the job market (European Commission, 2010).

In terms of their specific content, programs and courses should be adapted to their different target group (according to level: BA, MA, PhD; and according to the field of study: economics/business, science and technical studies, human sciences, arts and design, etc.). The higher the level of studies, the more complex and more associated with the real business environment should be the teaching content.

The content of courses on entrepreneurship is similar for all the fields of study, but, in order for it to answer the specific needs of different categories, usually one or another aspect is emphasized more. 
Entrepreneurship in business and economics schools is focused in business start-up, creating new adventures, and managing and growth of SMEs; entrepreneurship in engineering and exact sciences schools is especially focused in exploring intellectual property rights, creation of spin-off companies and in risk, offering courses, like management techniques, marketing, commercialization and sale of technologies based on ideas, patent registering and protection of idea-based technologies, financing and internationalization of hi-tech adventures; for human science students the focus should be in self-management and social entrepreneurship, which in fact is fast growing and is predicted to make a great difference in the social context of communities; entrepreneurship in arts and design is focused more in the emerging opportunities, creative work and creativity, preparing students who can work as freelancers or who can be self-employed, or create small businesses (European Commission, 2008).

Teaching methods should be action-oriented and to involve students, which could teach them "how to ...", so that they can easily understand the theoretic aspects. It is also important the inclusion of "outside lecturers" in the teaching process. They bring their own experience in entrepreneurship and students will take inputs from real life experiences.

It is preferred to have teaching methods based on "group/team techniques for creating a new business idea" and using "study cases". Continuing in this direction, a very useful means is the use of business planning workshops, employing brainstorming techniques, having invited lecturers, and "business simulation". At the same time, techniques on undertaking partial and practical activities on entrepreneurship and creativity exercises will bring about development of ideas emphasizing on creativity. Experts underline the importance of "crossing boundaries" among disciplines and the work in groups.

Independent of the level of students, a powerful teaching method in entrepreneurship is to mix business with nonbusiness students, which is actually achieved with the students of the Professional Master level. It is always significant for the participants, who make an effort to learn from each other and to discover new ways of thinking.

Lecturers should have academic formation, as well as prior experience in business, consulting or personal initiatives in entrepreneurship. It would be ideal if they had personal relations to the business world. The best lecturers are those who have the right teaching competences, as well as professional experience in the private sector. Training schemes should be set up for those lacking such an experience.

However, incentives to motivate the academic staff to engage in entrepreneurship teaching and similar activities with students are missing. For as long as publications is the main promotion criteria, project-oriented practices are not taken into consideration.

On the other hand, since not all the lecturers have practical experience, it is necessary to include the real entrepreneurs. They could play a crucial role especially during the business plan seminars or in group assignments.

Presentation of lectures by real life entrepreneurs is not only important because of the knowledge that they convey, but also for the example they set for the students to follow. A good option to achieve this is to work with the alumni, and the best universities build and maintain a very good network with their alumni, who could bring in knowledge and funding.

\subsection{Does our higher education guarantee the development of entrepreneurship mentality and capabilities?}

The Albanian education system is being reformed in all its cycles of study, widely taking into consideration the EU programs. The higher education reform is being implemented under a master plan, drafted time ago. Yet, there is still no clear indication to the Base Competences (Centre for Promoting Human Development [Qendra për Nxitjen e Zhvillimit Njerëzor], 2007). From a legal point of view, there many specific laws concerning higher education, which have not yet answered a number of issues: development of human resources, eradication of all obstacles for the autonomy of universities, undertaking an all-encompassing high quality reform, which would include all academicians, professors and students.

In light of these new economic and social conditions in the country, as well as the massification of higher education, we brought forward the hypothesis that: the BA - MA study cycle does not create premises for the development of entrepreneurship mentality and self-confidence in students, so that self-employment can be a way to enter the job market.

To this end, we surveyed bachelor and master (professional and scientific) students in the European University of Tirana, respectively: 100 BA students of second year in finance-banking, 70 BA students of second year in business management, and 40 professional and scientific master students in business management.

The survey included questions, divided into different categories: (i) understand of learning; (ii) how students perceive the future; (iii) the opportunities they have had during studies to learn about entrepreneurship, entrepreneurs 
and business ideas development; (iv) how they feel about themselves and what are the things they like to do; (v) what have they acquired from the studies take; (vi) how they perceive their future job; and (vii) how they identify an entrepreneur.

Students are little convinced that to become rich ( $85 \%$ of those surveyed) and successful (55\% of those surveyed) in Albania is important to study and be a very good student. Furthermore, they dedicate success to family connections and other close relations ( $65 \%$ of those surveyed share this opinion).

In general, students see their future profession in doing no-risk jobs (75\% of those surveyed), yet for them is important to work somewhere where they can learn continually new things ( $97 \%$ of those surveyed) or where they can have new possibilities ( $92 \%$ of those surveyed) and where they can earn a lot (95\% of those surveyed). It is to be noted a contradiction in the answers given by the master level students, who want a no-risk job (75\% of those surveyed), and yet they look for their professional advancement where they may take their own decisions ( $58 \%$ of those surveyed).

In relation to the category of questions about the opportunities they have had to know entrepreneurship and entrepreneurs, as well as the development of business ideas, there is a difference between BA and MA level students. But, similar to both groups is the lack of knowledge as to whom or where they should go for help if they have a business idea.

In relation to the category of what they expect to learn from the studies taken, the first preference of the BA students is the possibility to find a job, meanwhile the master level students indicate the ability to better perform in their job. More opportunity to start their own business is listed second from last from both groups. This clearly shows that university education does not bring about self-confidence, which an enterprise needs. Students with entrepreneurship capacities are less inclined to further their studies from the BA level towards MA, and even less to continue from BA to $\mathrm{MA}$ and $\mathrm{PhD}$ (result taken from informal meetings with $\mathrm{PhD}$ candidate students in business management of the European University of Tirana).

It was interesting to see that students had the right knowledge and perceptions about the entrepreneurship and entrepreneurs, and their main elements, and this was shown in the 10 questions in the survey concerning this category. Yet, their answers showed also the lack of self-confidence that entrepreneurship could be the career move for them.

\section{Conclusions and Recommendations}

Entrepreneurship education should be valued like all other aspects of the academic excellence, because a high level of academic performance does not only refer to the ability to analyze and reflect on knowledge, but it refers to the application for a given purpose, too.

The lack of experience in our universities on entrepreneurship and self-confidence are the two main reasons why the graduates do not engage in entrepreneurship. Students who have the enterprise abilities are little interested in furthering their studies from BA level to MA and PhD. This makes it necessary to use action-oriented teaching methods, which actually require intensive and costly work, as well as specific training. Entrepreneurship should be horizontally included in the curricula of different fields of study.

Entrepreneurship education required a multidimensional cooperation. The effective cooperation between the universities and SMEs requires an environment where both parties may profit, and for this to happen universities should make their cooperation long-term oriented, including entrepreneurs and business leaders as mentors and councilors, or developing courses of leadership and entrepreneurship, including also internships. To the SMEs should be offered shortterm returns, for example: through involving groups of students in innovation activities, especially in formulating and developing innovative ideas.

Universities should be more open to accept the experience of entrepreneurs, as an added base value to their lecturers. The number of part-time positions could be increased to accommodate them, as well as the opening of new positions for the highly educated academic staff with business and entrepreneurship experience and limited research experience.

Promotion of professional networks to regularly share teaching practices and methodologies; short-term cooperation among entrepreneurship lecturers and among universities in order to highlight best practices and methods employed; short-term internships of lecturers with enterprises, as well as encouraging close relations to the student organizations and alumni contributions.

Engagement in entrepreneurship of our universities requires dedicated and supportive incubators, or easy access to such outside facilities. The 2011 - 2016 National Innovation Strategy should quickly facilitate the cooperation among businesses and universities, as well as governmental institutions, and to help build such incubating hubs to serve 
universities. Financial grants to support entrepreneurship and/or other sources of financing.

\section{References}

Drucker. (1985). Innovation and entrepreneurship. New York: Harper \& Row.

European Commission. (2012). Effects and impact of entrepreunership programmes in higher education. Brussels: Entrepreunership Unit, Directorate-Generals for Entreprise and Industry.

European Commission. (2008). Entrepreneurship in higher education, especially within non-business studies. Entreprise and Industry Directorate -General.

European Commission. (2010). Towards Greater Cooperation and Cohenrence in Entrepreunership Education. Birmingham, United Kingdom: Vincent House.

Gaspar, Bierman, Kolari, Hise, Smith, \& Arreola-Risa. (2007). An Introduction to Business. Oxford University Press.

INSTAT. (2012, August 3). http://www.instat.gov.al. Retrieved 2012.

INSTAT. (2011). Rregjistrimi i Përgijthshëm i Popullsisë dhe i Banesave. INSTAT.

Instituti i Statistikës (INSTAT). (2009). Anketa e Forcave të Punës (AFP). Tiranë: INSTAT.

MES [MASH]. (2012).

Qendra për Nxitjen e Zhvillimit Njerëzor [Centre for Promoting Human Development]. (2007). Kompetenca e të mësuarit për të nxënë dhe e të mësuarit të sipërmarrjes në arsimin e mesëm profesional dhe në arsimin e lartë në Shqipëri. Torino: ETF.

Ruskovaara, E., Pihkala, T., Rytkola, T., \& Leino, J. S. (2010). Entrepreneurship in Entrepreneurship Education.

Smith, K., \& Petersen, J. L. (2006). What Is Educational Entrepreneurship? Harward Education Press, 30. 